\title{
Perilaku Tidak Etis Akuntan: Melihat dari Persepsi Mahasiswa Akuntansi Politeknik Negeri Malang
}

\author{
Ahmad Mustofa \\ Politeknik Negeri Malang \\ ahcmadmustofa@gmail.com \\ Kurnia Ekasari \\ Politeknik Negeri Malang \\ kurnia_es@yahoo.com.au \\ Kartika Dewi Sri Susilowati \\ Politeknik Negeri Malang \\ dewisri9@yahoo.com \\ (Diterima: 12-Juni-2020; dipublikasikan: 31-Juli-2020)
}

\begin{abstract}
The purpose of this research was to determine the effect of ethical orientation of idealism and ethical knowledge on the accountant's unethical behavior from the perception of accounting students. This research was conducted to students majoring in accounting at the State Polytechnic of Malang at least Accounting, Management Accounting, and Finance study programs. The data used are primary data in the form of an online questionnaire (google form). This type of research is a quantitative descriptive using SPSS analysis. The population of this study was 439 students with a sample counted 210 respondents using purposive sampling and the Slovin formula with an accuracy rate of $95 \%$. The results of this study indicate that the ethical orientation of idealism does not significantly influence the accountant's unethical behavior, while ethical knowledge has a negative and significant effect on the accountant's unethical behavior. However, the ethical orientation of idealism and ethical knowledge together significantly influence the accountant's unethical behavior.
\end{abstract}

Keywords: Ethical Orientation; Ethical Knowledge; Ethical Behavior of Accountants; Student Perceptions.

\begin{abstract}
Abstrak
Tujuan dari penelitian ini untuk mengetahui pengaruh orientasi etis idealisme dan pengetahuan etika terhadap perilaku tidak etis akuntan melihat dari persepsi mahasiswa akuntansi. Penelitian ini dilakukan kepada mahasiswa jurusan akuntansi Politeknik Negeri Malang dengan program studi Akuntansi, Akuntansi Manajemen dan Keuangan. Data yang digunakan adalah data primer berupa kuesioner online (googleform). Jenis penelitian ini adalah deskriptif kuantitatif yang menggunakan alat bantu analisis SPSS. Populasi penelitian ini sebanyak 439 mahasiswa dengan hasil sampel 210 responden menggunakan purposive sampling dan rumus slovin dengan tingkat akurasi 95\%. Hasil penelitian ini menunjukkan bahwa orientasi etis idealism tidak berpengaruh signifikan terhadap perilaku tidak etis akuntan, sedangkan pengetahuan etika berpengaruh negatifa dan signifikan terhadap perilaku tidak etis akuntan. Namun, orientasi etis idealism dan pengetahuan etika bersama-sama berpengaruh signifikan terhadap perilaku tidak etis akuntan.
\end{abstract}

Kata Kunci: Orientasi Etis; Pengetahuan Etika; Perilaku Etis Akuntan; Persepsi Mahasiswa. 


\section{PENDAHULUAN}

Setiap profesi pasti dituntut untuk bekerja secara profesional. Dalam menjalankan profesi, kompetensi dan kemampuan yang khusus harus dimiliki agar bersaing dengan profesi lainnya. Namun, selain kompetensi dan kemampuan khusus, suatu profesi harus memiliki etika yang merupakan aturan yang harus ditaati oleh pihak yang menjalankan profesi tersebut. Bagaimana pun etika menjadi dasar atau konsep yang harus ditetapkan dalam bidang profesi. Prihanto (2018) menyatakan bahwa melalui etika, manusia dapat berperilaku terhadap apa yang dapat diterima maupun tidak diterima dalam organisasi dan masyarakat. Perilaku dan tindakan etis menjadi bagian penting dalam menjaga kepercayaan masyarakat terhadap bidang profesi. Guna menjaga agar setiap anggota profesi berperilaku dan bertindak etis maka dibuatlah peraturan berdasarkan prinsip moral pada umumnya yang disesuaikan dengan jenis profesi dalam bentuk kode etik profesi.

Etika suatu profesi menjadi topik pembicaraan yang sangat penting dalam masyarakat sekarang ini. Terjadinya pelanggaran etika profesi di dunia tak terkecuali Indonesia menyadarkan masyarakat untuk mengutamakan perilaku etis, dimana selama ini perilaku etis sering di abaikan. Etika menjadi kebutuhan penting bagi semua profesi yang ada agar tidak melakukan tindakan yang menyimpang hukum. Semua profesi dituntut untuk berperilaku etis yaitu bertindak sesuai dengan moral dan nilai-nilai yang berlaku.

Prinsip etika dalam profesi akuntansi yang ditetapkan oleh Ikatan Akuntan Indonesia (IAI) yang berlaku sejak tahun 1998 diantaranya memuat 8 (delapan) prinsip antara lain: Tanggung Jawab Profesi, Kepentingan Publik, Integritas, Objektivitas, Kompetensi dan Kehati-hatian Profesional, Kerahasiaan, Perilaku Profesional dan Standar Teknis (Prihanto, 2018). Big and Blocher (1998) dalam Prihanto (2018) mengemukakan bahwa terdapat tiga fungsi dari kode etik antara lain: melindungi profesi dari campur tangan pemerintah, mencegah terjadinya pertentangan internal dalam profesi, dan melindungi para praktisi dari kesalahan praktik suatu profesi. Akan tetapi, dalam praktiknya seorang akuntan sering dihadapkan dengan dilema etis dimana seorang akuntan harus mengambil keputusan tentang perilaku yang tepat dan sesuai dengan aturan kode etik profesi dalam melakukan pekerjaannya.

Dilema etis yang dihadapi oleh para akuntan tidak jarang menimbulkan tindakantindakan yang melanggar kode etik profesi akuntan. Menurut Arens et al (2010) dalam Adi (2019) ada dua alasan mengapa seorang bertindak tidak etis yang pertama standar etika seseorang berbeda dengan standar etika yang berlaku di masyarakat umum dan yang kedua orang memilih untuk bertindak mementingkan diri sendiri. Salah satu skandal akuntansi yang melibatkan akuntan adalah yang dilakukan oleh British Telecom dan terindikasi pada tahun 2017. Pelanggaran akuntansi yang dilakukan oleh British Telecom terjadi di salah satu jenis usahanya di Italia. Price Waterhouse Coopers (PwC) sebagai akuntan public terkena dampak fraud yang dilakukan oleh British Telecom, yang mana PwC merupakan kantor akuntan publik ternama di dunia dan termasuk the bigfour Accounting Firms. Kecurangan akuntansi British Telecom gagal dideteksi oleh $\mathrm{PwC}$ dan justru berhasil dideteksi oleh pelapor pengaduanyang dilanjutkan dengan akuntansi forensik oleh KPMG. Modus kecurangan akuntansi yang dilakukan British Telecom di Italia relatif sederhana yakni melakukan peningkatan atas laba perusahaan selama beberapa tahun menggunakan cara yang tidak etis melalui kerjasama koruptif dengan klien-klien perusahaan dan jasa keuangan.

Sedangkan di Indonesia, pelanggaran kode etik beberapa kali terjadi. Seperti yang melibatkan Kantor Akuntan Publik mitra Ernst \& Youngs (EY) di Indonesia yaitu Kantor Akuntan Publik Purwantono, Suherman \& Surja. Kasus tersebut berawal pada tahun 2012 ketika Kantor Akuntan Publik mitra EY di AS melakukan kajian atas hasil audit kantor akuntan di Indonesia. ditemukan bahwa hasil audit atas perusahaan telekomunikasi yang dilakukan afiliasi Ernst \& Youngs (EY) di Indonesia tidak didukung dengan data yang akurat, yakni dalam hal persewaan lebih dari 
empat ribu unit menara seluler, namun afiliasi EY di Indonesia merilis laporan hasil audit dengan status wajar tanpa pengecualian. Akibatnya KAP EY dikenakan denda sebesar US\$ 1 juta oleh Badan Pengawas Perusahaan Akuntan Publik Amerika Serikat (Public Company Accounting Oversight Board) (Adi, 2019). Beberapa skandal akuntansi yang terjadi baik di luar maupun di dalam negeri merusak citra baik dari profesi akuntan, dan secara tidak langsung akan berpengaruh terhadap opini dan persepsi masyarakat, dimana kelompok masyarakat tersebut diantaranya adalah mahasiswa.

Mahasiswa jurusan akuntansi mempelajari etika dan bisnis di suatu organisasi dalam bentuk mata kuliah etika bisnis, pengauditan dan perilaku organisasi.. Hal Ini memberikan mereka pemahaman mengenai sikap etis dan etika dalam berorganisasi, independensi, integritas dan objektifitas dalam melakukan pekerjaan. Salah satu bidang profesi yang tersedia adalah profesi auditor dan akuntan, baik auditor internal maupun eskternal dan akuntan perusahaan maupun akuntan publik. Profesi ini adalah salah satu bahan pertimbangan bahkan menjadi profesi favorit bagi mahasiswa jurusan akuntansi dalam memilih karir sebagai seorang auditor atau akuntan dimasa yang akan datang. Bahan pertimbangan lainnya yang mempengaruhi persepsi mahasiswa yaitu dengan banyaknya kecurangan yang terjadi terkait pelanggaran etika dan integeritas yang telah dipaparkan diparagraf sebelumnya.

Menurut Keraf (1998:230) ada dua teori etika yang dikenal sebagai etika deontologi dan teleologi.

\section{Etika Deontologi}

Istilah deontologi berasal dari bahasa Yunani yaitu deon, yang berarti kewajiban. Menurut etika deontologi suatu tindakan itu baik bukan dinilai dan dibenarkan berdasarkan akibat atau tujuan baik dari tindakan itu, melainkan berdasarkan tindakan itu sendiri sebagai baik pada dirinya sendiri. Dengan kata lain, tindakan itu bernilai moral karena tindakan itu dilaksanakan terlepas dari tujuan atau akibat dari tindakan itu.

\section{a. Etika Teleologi}

Berbeda dengan etika deontologi, etika teleologi justru mengukur baik buruknya suatu tindakan berdasarkan tujuan yang mau dicapai dengan tindakan itu, atau berdasarkan akibat yang ditimbulkan oleh tindakan itu. Suatu tindakan dinilai baik, kalau bertujuan mencapai sesuatu yang baik, atau kalau akibat yang ditimbulkannya baik dan berguna. Dengan dasar ini dapat dikatakan bahwa etika teleologi lebih bersifat situasional, karena tujuan dan akibat suatu tindakan bisa sangat tergantung pada situasi khusus tertentu.

Salah satu faktor yang mempengaruhi persepsi mahasiswa akuntansi terhadap perilaku tidak etis akuntan yaitu orientasi etis dan pengetahuan etis. Tujuan dari penelitian ini untuk mengetahui pengaruh orientasi etis idealism dan pengetahuan etika terhadap persepsi mahasiswa atas perilaku tidak etis akuntan.

Berdasarkan beberapa penelitian terdahulu, orientasi etis idealisme berpengaruh terhadap persepsi mahasiswa akuntansi atas perilaku tidak etis akuntan. Pernyataan tersebut didukung dengan penelitian Mardawati (2014) bahwa orientasi etis idealisme berpengaruh negatif terhadap persepsi mahasiswa akuntansi atas perilaku tidak etis akuntan, hasil tersebut sesuai dengan penelitian Damayanthi (2016) dan Sumiyantini (2017). Sedangkan pada penelitian Diwi (2015) orientasi etis berpengaruh positif terhadap persepsi mahasiswa jurusan akuntansi atas perilaku tidak etis akuntan. Hasil yang berbeda ditemukan Kholifah (2018), Adi (2019), dan Yuliani (2019) di mana orientasi etis idealisme tidak berpengaruh signifikan terhadap persepsi mahasiswa akuntansi atas perilaku tidak etis akuntan. Pengetahuan etika juga berpengaruh terhadap persepsi mahasiswa atas perilaku tidak etis akuntan. Pernyataan tersebut sesuai dengan penelitian Mardawati (2014) yang menunjukkan bahwa pengetahuan etika berpengaruh negatif kepada persepsi mahasiswa terhadap perilaku tidak etis akuntan. Hasil tersebut juga sesuai dengan penelitian Damayanthi (2016), Sumiyantini (2017), dan Adi (2019) bahwa tingkat pengetahuan memiliki pengaruh negatif terhadap perilaku tidak etis 
akuntan. Hasil penelitian diatas tidak selalu konsisten dengan hasil yang diharapkan dikarenakan kriteria dalam pengambilan sampel hanya menggunakan mata kuliah pengauditan dan etika bisnis. Penelitian ini akan mengembangkan dari segi kriteria yang diberikan dengan mata kuliah perilaku organisasi dan bagaimana persepsi dari mahasiswa akuntansi Politeknik Negeri Malang, yang nantinya diharapkan dapat menambah akurasi dalam persepsi mahasiswa akuntansi terhadap perilaku tidak etis akuntan.

\section{METODE PENELITIAN}

Penelitian ini merupakan penelitain kuantitatif deskriptif. Sugiyono (2017) menyatakan bahwa metode penelitian kuantitatif dapat diartikan sebagai metode penelitian yang berlandaskan pada filsafat positivisme, digunakan untuk meneliti pada populasi atau sampel tertentu, pengumpulan data menggunakan instrumen penelitian, analisis data bersifat statistik, dengan tujuan untuk menguji hipotesis yang telah ditetapkan, dimana dalam konteks penelitian ini hipotesis yang diajukan adalah untuk menggambarkan bagaimana persepsi mahasiswa akuntansi atas perilaku tidak etis akuntan.

Jenis data dalam penelitian ini adalah data primer yang diperoleh melalui penyebaran kuesioner secara online menggunakan google form. Populasi dalam penelitian ini adalah mahasiswa akuntansi Politeknik Negeri Malang dari program studi DIII Akuntansi angkatan 2018, DIV Akuntansi Manajemen angkatan 2017, dan DIV Keuangan angkatan 2017 dengan total 439 mahasiswa. Teknik pengambilan sampel menggunakan metode Purposive Sampling dengan kriteria mahasiswa yang telah menempuh mata kuliah pengauditan, pengauditan manajemen, etika bisnis dan tata kelola perusahaan, dan perilaku organisasi. Penentuan jumlah sampel dihitung menggunakan rumus slovin dengan nilai akurasi $95 \%$ menghasilkan sampel 210 responden.

Kuesioner penelitian ini menggunakan skala Likert dengan empat alternatif pilihan jawaban. Responden diminta untuk mengisi setiap jawaban atas pertanyaan dalam bentuk pilihan yang sudah ditentukan dan masingmasing jawaban tersebut diberikan skor sesuai kriteria jawaban responden. Pada kuesioner ini mengadaptasi dari Mardawati (2014) yang telah dikembangkan dan direaplikasikan oleh Adi (2019). Berdasarkan hasil diatas, maka dapat dirumuskan hipotesis penelitian sebagai berikut "Orientasi etis dan pengetahuan etika, baik secara simultan maupun parsial berpengaruh signifikan terhadap persepsi mahasiswa akuntansi atas perilaku tidak etis akuntan". Dari hasil tersebut, maka terbentuklah kerangka penelitian yang dapat dilihat pada gambar 1 .

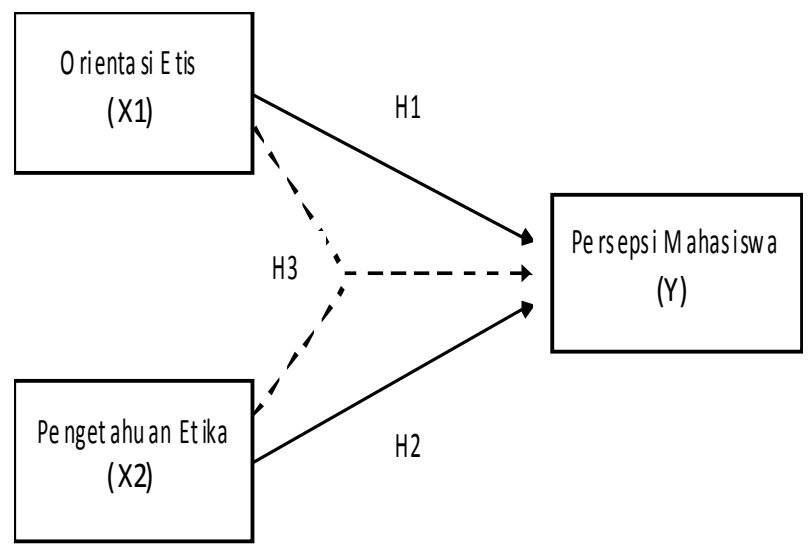

Gambar 1 Kerangka Penelitian

\section{HASIL DAN PEMBAHASAN}

\section{Hasil Statistik}

Responden yang mengisi kuesioner telah memenuhi sampel sebanyak 210 responden. Kuesioner disebar secara online melalui google form kepada mahasiswa akuntansi Politeknik Negeri Malang. Penyebaran kuesioner dimulai 04 Mei 2020 sampai dengan 10 Mei 2020 dengan sistem share media social.

Sebanyak 249 kuesioner yang berhasil dihimpun. Dari 249, 210 kuesioner yang terisi secara lengkap dan layak untuk diujikan kedalam sampel. Dengan demikian telah memenuhi kuota sampel yang telah disyaratkan.

\section{Uji Kualitas Data}

Pengujian ini terdiri dari dua bagian yaitu :

1. Uji Validitas

Uji Validitas digunakan untuk mengukur keakuratan. valid atau tidaknya suatu instrument penelitian yang digunakan untuk 
memperoleh data dalam suatu penelitian. Menurut Sugiyono (2017) valid berarti instrumen tersebut dapat digunakan untuk mengukur apa yang seharusnya diukur.

Tabel 1. Uji Validitas

\begin{tabular}{|c|c|c|c|}
\hline $\begin{array}{c}\text { Item } \\
\text { Pernyataan }\end{array}$ & $\begin{array}{c}\text { Nilai } \\
\text { Pearson }\end{array}$ & r Tabel & Keputusan \\
\hline Y.P1 & 0,561 & 0,148 & Valid \\
\hline Y.P2 & 0,541 & 0,148 & Valid \\
\hline Y.P3 & 0,762 & 0,148 & Valid \\
\hline Y.P4 & 0,731 & 0,148 & Valid \\
\hline Y.P5 & 0,766 & 0,148 & Valid \\
\hline X1.P1 & 0,52 & 0,148 & Valid \\
\hline X1.P2 & 0,591 & 0,148 & Valid \\
\hline X1.P3 & 0,651 & 0,148 & Valid \\
\hline X1.P4 & 0,644 & 0,148 & Valid \\
\hline X1.P5 & 0,623 & 0,148 & Valid \\
\hline X1.P6 & 0,667 & 0,148 & Valid \\
\hline X1.P7 & 0,579 & 0,148 & Valid \\
\hline X1.P8 & 0,653 & 0,148 & Valid \\
\hline X1.P9 & 0,639 & 0,148 & Valid \\
\hline X1.P10 & 0,601 & 0,148 & Valid \\
\hline X2.P1 & 0,599 & 0,148 & Valid \\
\hline $\mathrm{X} 2 . \mathrm{P} 2$ & 0,778 & 0,148 & Valid \\
\hline X2.P3 & 0,647 & 0,148 & Valid \\
\hline $\mathrm{X} 2 . \mathrm{P} 4$ & 0,698 & 0,148 & Valid \\
\hline X2.P5 & 0,643 & 0,148 & Valid \\
\hline X2.P6 & 0,61 & 0,148 & Valid \\
\hline X2.P7 & 0,712 & 0,148 & Valid \\
\hline X2.P8 & 0,755 & 0,148 & Valid \\
\hline $\mathrm{X} 2 . \mathrm{P} 9$ & 0,539 & 0,148 & Valid \\
\hline X2.P10 & 0,783 & 0,148 & Valid \\
\hline
\end{tabular}

Sumber : Hasil Penelitian (data telah diolah), 2020

Tabel 1 menunjukkan hasil uji validitas yang valid untuk seluruh item pertanyaan. Hal tersebut berdasarkan $r$-hitung yang lebih besar daripada r-tabel.

2. Uji Reliabilitas

Uji realibitas digunakan untuk menguji keandalan instrument yang apabila digunakan beberapa kali objek yang sama, maka akan menghasilkan data yang serupa pula (Sugiyono, 2017).
Tabel 2 Uji Reliabilitas

\begin{tabular}{|c|c|c|c|}
\hline Variabel & Y & $\mathrm{X} 1$ & $\mathrm{X} 2$ \\
\hline Cronbach's Alpha & 0,692 & 0,823 & 0,859 \\
\hline Item Pertanyaan & 5 & 10 & 10 \\
\hline Keputusan & Reliabel & Reliabel & Reliabel \\
\hline \multicolumn{4}{|c|}{ Sumber : Hasil Penelitian (data telah diolah), 2020} \\
\hline \multicolumn{4}{|c|}{$\begin{array}{l}\text { Nilai Cronbach's alpha dari table } 2 \text { menun- } \\
\text { jukkan hasil diatas } 0,60 \text {. Hal ini diartikan } \\
\text { bahwa data reliable. }\end{array}$} \\
\hline
\end{tabular}

Uji Asumsi Klasik

Uji asumsi klasik terbagi menjadi empat yaitu, uji normalitas data, multikolinieritas, heteroskedastisitas, dan autokorelasi.

1. Uji Normalitas data

Uji normalitas data digunakan untuk menguji apakah data tersebut sudah berdistribusi normal atau tidak. Kolgomorov-Smirnov digunakan untuk menguji normalitas data.

Tabel 3 Uji Normalitas data One-Sample Kolmogorov-Smirnov Test

\begin{tabular}{llr}
\hline \multicolumn{2}{l}{ Unstandardized Residual } & \\
\cline { 1 - 1 } & & 210 \\
Normal Parametersa,b & Mean & 0,0454662 \\
& $\begin{array}{l}\text { Std. De- } \\
\text { viation }\end{array}$ & 1,9385564 \\
\hline & Absolute & 0,055 \\
Most Extreme Differences & Positive & 0,055 \\
& Negative & $-0,039$ \\
\hline Test Statistic & & 0,055 \\
\hline Asymp. Sig. (2-tailed) & & $, 241 \mathrm{c}, \mathrm{d}$ \\
\hline
\end{tabular}

Sumber : Hasil Penelitian (data telah diolah), 2020

Tabel 3 uji normalitas data diatas diperoleh nilai D-hitung (Absolute) sebesar 0,055 lebih kecil dari nilai D-tabel dengan jumlah $\mathrm{N}=210$ yaitu sebesar 0,155 dan nilai Asymp. Sig. (2-tailed) sebesar 0,241 lebih besar dari 5\% (0,05). Dari data diatas menunjukkan bahwa data tersebut berdistribusi normal.

2. Uji Multikolinearitas

Uji ini bertujuan untuk mengetahui apakah ada korelasi antara variabel bebas. Yudiatmaja (2013) menyatakan Jika antara 
variabel bebas tersebut berkorelasi sangat kuat, maka secara logika persamaan regresinya cukup diwakili oleh salah satu variabel saja.

Tabel 4 Uji Multikolinieritas Coefficients ${ }^{\mathrm{a}}$

\begin{tabular}{lcl}
\hline \multirow{2}{*}{ Model } & \multicolumn{2}{c}{ Collinearity Statistics } \\
\cline { 2 - 3 } & Tolerance & VIF \\
\hline Orientasi Etis & 0,746 & 1,537 \\
\hline Pengetahuan Etika & 0,832 & 1,653 \\
\hline
\end{tabular}

Sumber : Hasil Penelitian (data telah diolah), 2020

Pada tabel 4 di atas dapat diketahui bahwa nilai tolerance untuk kedua variabel independen lebih besar dari $10 \%(0,1)$ dan nilai VIP untuk kedua variabel lebih kecil dari 10. Dengan demikian tidak terjadi multikolinearitas.

3. Uji Heteroskedastisitas

Uji ini bertujuan untuk menguji keidaksamaan varian dari residual satu pengamatan ke pengamatan lainnya. Maka dari itu biasanya digunakan uji Glejser.

Tabel 5 Uji Heterokedastisitas

\begin{tabular}{lrlll}
\hline Model & df & $\begin{array}{l}\text { Mean } \\
\text { Square }\end{array}$ & F & Sig. \\
\cline { 1 - 3 } Regression & 2 & 2,374 & & \\
\cline { 1 - 3 } Residual & 207 & 1,56 & 1,569 & \multirow{2}{*}{$205 \mathrm{~b}$} \\
\cline { 1 - 3 } Total & 210 & & \\
\hline
\end{tabular}

Sumber : Hasil Penelitian (data telah diolah), 2020

Tabel 5 menunjukkan nilai $\mathrm{F}$ hitung sebesar 1,569 lebih kecil dari nilai $F$ tabel yaitu sebesar 3,05. Hal ini menunjukkan bahwa variabel bebas tidak signifikan dalam menjelaskan variasi yang terjadi pada variabel dependen.

Dapat dikatakan bahwa tidak satupun variabel independen yang signifikan secara statistik mempengaruhi nilai absolut variabel dependen atau dapat dikatakan bahwa tidak terdapat gejala heteroskedastisitas dalam model regresi dalam penelitian ini.

\section{Uji Hipotesis}

Uji hipotesis terbagi menjadi tiga yaitu, analisis korelasi dan determinasi, uji t parsial, dan uji F simultan.
1. Koefisien Korelasi (R) dan Determinasi $\left(\mathrm{R}^{2}\right)$

Uji analisis korelasi ganda digunakan untuk menguji korelasi linear antara satu variabel dependen (Y) dengan beberapa (dua atau lebih) variabel independen (X) (Widiyanto, 2013).

Tabel 6 Uji Koefisien Korelasi dan Determinasi

\begin{tabular}{|c|c|c|c|}
\hline \multicolumn{4}{|c|}{ Model Summary } \\
\hline $\mathrm{R}$ & $\begin{array}{c}\mathrm{R} \\
\text { Square }\end{array}$ & $\begin{array}{l}\text { Adjusted R } \\
\text { Square }\end{array}$ & $\begin{array}{l}\quad \text { Std. } \\
\text { Error of the } \\
\text { Estimate }\end{array}$ \\
\hline ,364a & 0,139 & 0,126 & 1,947 \\
\hline
\end{tabular}

Sumber : Hasil Penelitian (data telah diolah), 2020

Uji Koefisien determinasi dilakukan untuk menghitung besar kontribusi variabel orientasi etis dan pengetahuan etika terhadap persepsi mahasiswa akuntansi atas perilaku tidak etis akuntan. Koefisien determinasi adalah besarnya kontribusi variabel bebas terhadap variabel terikat (Widiyanto, 2013)

berdasarkan tabel 6 diatas besarnya nilai (R) adalah 0,364 atau $36,4 \%$. Hal ini menunjukkan bahwa antara variabel orientasi etis dan pengetahuan etika memiliki hubungan yang kurang kuat terhadap variabel persepsi mahasiswa akuntansi atas perilaku tidak etis akuntan.

Berdasarkan pada tabel 7 menunjukkan bahwa besarnya nilai Adjusted R2 adalah 0,126 atau sebesar 12.6\%. Hal tersebut menunjukkan variabel orientasi etis idealisme dan pengetahuan etika mampu menjelaskan variabel persepsi mahasiswa akuntansi atas perilaku tidak etis akuntan sebesar $12,6 \%$, sisanya sebesar $87,4 \%$ dijelaskan oleh faktor lainnya yang tidak diuji atau digunakan dalam penelitian ini.

Selanjutnya akan dilakukan pengujian regresi linier berganda. Regresi Linier Berganda digunakan untuk meramalkan bagaimana keadaan (fluktuasi) variabel dependen (kriteria), bila dua atau lebih variabel inde- 
penden sebagai faktor prediktor dimanipulasi. (Sugiyono, 2017).

Tabel 7 Uji Regresi Linier Berganda

\begin{tabular}{lcc}
\hline \multirow{2}{*}{ Model } & \multicolumn{2}{c}{ Unstandardized Coefficients } \\
\cline { 2 - 3 } & $\mathrm{B}$ & Std. Error \\
\hline (Constant) & 14,776 & 1,489 \\
\hline Orientasi Etis & 0,042 & 0,055 \\
\hline Pengetahuan Etika & $-0,194$ & 0,039 \\
\hline
\end{tabular}

Sumber : Hasil Penelitian (data telah diolah), 2020

Berdasarkan tabel 8 uji regresi linier berganda, maka dapat diperoleh persamaan regresi linier dibawah ini.

$\mathrm{Y}=14,776+0,042 \mathrm{X} 1-0,194 \mathrm{X} 2+\mathrm{e}(1)$

Dari persamaan regresi (1) diketahui bahwa konstanta regresi mempunyai nilai 14,776 yang menunjukkan bahwa jika variabel orientasi etis dan pengetahuan etika tidak ada, maka nilai dari variabel persepsi mahasiswa akuntansi atas perilaku tidak etis akuntan mempunyai nilai konstan sebesar 14,776. Berdasarkan hasil persamaan regresi linier berganda tersebut dapat dijelaskan bahwa:

1. Koefisien variabel orientasi etis idealisme mempengaruhi persepsi mahasiswa akuntansi atas perilaku tidak etis akuntan sebesar 0,042. Hal ini menunjukkan apabila nilai orientasi etis idealisme meningkat sebesar satu satuan, maka nilai persepsi mahasiswa akuntansi terhadap perilaku tidak etis akuntan akan meningkat sebesar 0,042 satuan.

2. Koefisien variabel pengetahuan etika mempengaruhi persepsi mahasiswa akuntansi atas perilaku tidak etis akuntan sebesar 0,194. Hal ini menunjukkan apabila nilai pengetahuan etika meningkat sebesar satu satuan, maka nilai persepsi mahasiswa akuntansi atas perilaku tidak etis akuntan akan turun sebesar -0,194 satuan.

2. Uji Parsial (Uji t)

Uji ini dilakukan untuk mencari hubungan anatar variabel dependen dengan variabel independen dengan ketentuan apabila hasil $\mathrm{t}$ hitung $>\mathrm{t}$ tabel dengan taraf signifikan sebesar $5 \%$, maka variabel independen memiliki pengaruh yang signifikan terhadap variabel de- penden dan beigitu pun sebaliknya apabila $\mathrm{t}$ hitung $<\mathrm{t}$ tabel maka variabel tidak memiliki pengaruh signifikan (Widiyanto, 2013).

Tabel 8 Uji t (parsial)

\begin{tabular}{llll}
\hline & Model & $\mathrm{T}$ & Sig. \\
\hline \multirow{3}{*}{1} & (Constant) & 9,879 & 0,000 \\
\cline { 2 - 4 } & Orientasi Etis & 0,643 & 0,542 \\
\cline { 2 - 4 } & Pengetahuan Etika & $-4,417$ & 0,000 \\
\hline
\end{tabular}

Sumber : Hasil Penelitian (data telah diolah), 2020

Berdasarkan pada tabel 8 di, pada variabel $\mathrm{X} 1$ diperoleh nilai $\mathrm{t}$ hitung sebesar 0,643. Nilai $t_{\text {hitung }}$ yang dihasilkan lebih kecil dari pada nilai $t$ tabel yaitu sebesar 1,974. Dengan demikian $\left(\mathrm{H}_{1}\right)$ Orientasi etis idealisme berpengaruh signifikan terhadap persepsi mahasiswa akuntansi atas peilaku tidak etis akuntan ditolak.

Pada variabel $\mathrm{X} 2$ diperoleh nilai $\mathrm{t}$ hitung sebesar 4,417.Nilai $t$ hitung yang dihasilkan lebih besar dari pada nilai $t$ tabel yaitu sebesar 1,974. Nilai koefisien regresi menunjukkan arah hubungan negatif sebesar -0,194. Dengan demikian $\left(\mathrm{H}_{2}\right)$ Pengetahuan etika berpengaruh signifikan terhadap persepsi mahasiswa akuntansi atas peilaku tidak etis akuntan diterima.

3. Uji Simultan (uji F)

Uji ini dilakukan untuk menguji semua variabel independen terhadap variabel dependen secara bersama-sama dengan ketentuan apabila nilai $\mathrm{F}_{\text {hitung }}>\mathrm{F}_{\text {tabel }}$ dengan taraf signifikansi sebesar 5\%, maka terdapat pengaruh yang signifikan antara variabel in- dependen terhadap variabel dependen. Sebaliknya apabila nilai $\mathrm{F}_{\text {hitung }}<\mathrm{F}$ tabel maka tidak terdapat pengaruh yang signifikan antara variabel independen dengan variabel dependen.

\section{Tabel 9 Uji F}

\begin{tabular}{lrrrr}
\hline Model & Df & $\begin{array}{l}\text { Mean } \\
\text { Square }\end{array}$ & F & Sig. \\
\hline Regression & 2 & 47,863 & & \\
Residual & 208 & 3,976 & 12,577 &, $000 \mathrm{~b}$ \\
$\quad$ Total & 210 & & & \\
\hline
\end{tabular}

Sumber : Hasil Penelitian (data telah diolah), 2020 
Tabel 9 diperoleh nilai $\mathrm{F}$ hitung sebesar 12,577 yang lebih besar dari nilai $\mathrm{F}$ tabel sebesar 3,05 dan nilai signifikansi sebesar 0,00 yang lebih kecil dari taraf signifikansi 5\% atau 0,05. Dengan demikian $\left(\mathrm{H}_{3}\right)$ hipotesis 3 diterima.

\section{Pembahasan}

Terdapat tiga hipotesis yang akan dijabarkan yaitu :

1. Pengaruh Orientasi Etis Idealisme terhadap Persepsi Mahasiswa Akuntansi atas Perilaku Tidak Etis Akuntan.

Hipotesis pertama menunjukkan bahwa orientasi etis idealisme berpengaruh terhadap persepsi mahasiswa akuntansi atas perilaku tidak etis akuntan. Hasil analisis yang diperoleh menunjukkan tingkat signifikansi sebesar 0,542 lebih besar dari 0,05 (5\%) dan nilai $t_{\text {hitung }}$ sebesar 0,643 lebih kecil dari pada nilai $t_{\text {tabel }}$ yaitu 1,974 sehingga orientasi etis tidak berpengaruh terhadap persepsi mahasiswa atas perilaku tidak etis akuntan yang menunjukkan $\mathrm{H}_{1}$ ditolak.

Adanya kesempatan mungkin bisa menjadi alasan mahasiswa untuk tidak berperilaku etis. Bukan hanya itu, kadang adanya keterpaksaan atau dilema etis yang terjadi kepada mahasiswa oleh perilaku pengajar mereka. Misalkan dalam pemberian tugas yang sangat sulit atau belum pernah diajarkan namun dijadikan sebagai bahan tugas. Hal ini sejalan dengan Adi (2019) yang menyatakan faktor eksternal dan keinginan pribadi dari dalam diri mahasiswa untuk mencapai tujuan tertentu sehingga membawa mereka ke tindakan tidak etis. Sehingga mahasiswa mengabaikan aturan etika yang berlaku.

2. Pengaruh Pengetahuan Etika terhadap Persepsi Mahasiswa Akuntansi atas Perilaku

Tidak Etis Akuntan

Hipotesis kedua menunjukkan bahwa pengetahuan Etika berpengaruh terhadap persepsi mahasiswa akuntansi atas perilaku tidak etis akuntan. Hasil analisis yang diperoleh menunjukkan tingkat signifikansi sebesar 0,000 lebih kecil dari $0,05(5 \%)$ dan nilai $t$ hitung menunjukkan hasil negatif sebesar 4,417 $>$ nilai $t_{\text {tabel }}$ yaitu 1,974 sehingga pengetahuan etika berpengaruh negatif terhadap persepsi mahasiswa atas perilaku tidak etis akuntan, sehingga $\mathrm{H}_{2}$ diterima.

Mahasiswa yang memiliki pengetahuan yang luas mengenai prinsip etika profesi akuntan akan bersikap dan bertindak lebih bijaksana dan memberikan pertentangan mengenai skandal etika yang menimpa profesi akuntan berkaitan dengan penerapan prinsip etika profesi akuntan dibandingkan dengan mahasiswa yang memiliki pengetahuan lebih sedikit. Sepakat dengan Indah (2019) yang menyatakan bahwa banyaknya informasi yang diperoleh oleh seseorang akan mempengaruhi pengetahuan yang dimiliki. Pengetahuan dapat diperoleh melalui proses belajar secara formal dan informal maupun berasal dari pengalaman. Pengetahuan memberikan informasi yang bermanfaat untuk mencari solusi atas berbagai permasalahan serta memberikan acuan dalam bertindak di masa sekarang maupun yang akan datang dengan mempelajari peristiwa yang telah terjadi di masa lampau. Pengetahuan etika yang dimiliki seseorang akan memberikan informasi berkaitan dengan suatu etika yang berlaku. Oleh karena itu, seorang yang memiliki pengetahuan etika akan bersikap atau berperilaku sesuai etika yang diketahuinya. Hal tersebut sesuai dengan teori tahapan perkembangan moral, dimana pada usia di atas 13 tahun, seseorang akan cenderung berorientasi pada etika. Semakin banyak atau luas pengetahuan etika yang dimiliki oleh seorang mahasiswa akuntansi, maka semakin rendah persepsi etis mahasiswa akuntansi atas perilaku tidak etis akuntan atau kemungkinan untuk melakukan perilaku tidak etis semakin rendah. Hal ini juga sesuai dengan penelitian yang dilakukan oleh Adi (2019), Damayanthi (2016), dan Mardawati (2014) yang menyatakan bahwa tingkat pengetahuan berpengaruh negatif pada persepsi mahasiswa akuntansi atas perilaku tidak etis akuntan.

3. Pengaruh Orientasi Etis Idealisme dan Pengetahuan Etika Secara Bersama terhadap Persepsi Mahasiswa Jurusan Akuntansi atas Perilaku Tidak Etis Akuntan.

Hipotesis ketiga menunjukkan bahwa orientasi etis idealisme dan pengetahuan etika secara bersama-sama berpengaruh terhadap 
persepsi mahasiswa akuntansi atas perilaku tidak etis akuntan. Hasil analisis yang diperoleh menunjukkan tingkat signifikansi sebesar 0,000 lebih kecil dari 0,05 (5\%) dan nilai $\mathrm{F}_{\text {hitung }}$ sebesar 12,577 > $\mathrm{F}_{\text {tabel }}$ yaitu 3,05 sehingga orientasi etis idealisme dan pengetahuan etika secara bersama-sama berpengaruh terhadap persepsi mahasiswa akuntansi atas perilaku tidak etis akuntan. Berdasarkan hasil tersebut, maka bahwa $\mathrm{H} 3$ diterima.

Mahasiswa dengan tingkat idealis dan pengetahuan yang luas akan lebih sadar akan pentingnya perilaku etis dan tidak setuju akan skandal etis yang menimpa profesi akuntan. Mereka sadar bahwa semua harus berjalan sesuai kode etik agar integeritas dari profesi akuntan terjaga.

\section{KESIMPULAN DAN SARAN}

\section{Kesimpulan}

Penelitian ini memberikan gambaran bahwa dengan tambahan mata kuliah perilaku organisasi memberikan hasil bahwa orientasi etis mahasiswa tidak berpengaruh terhadap perilaku tidak etik akuntan, sedangkan pengetahuan etika berpengaruh negatif terhadap perilaku tidak etis akuntan. Dan secara bersama-sama antara orientasi etis dan pengetahuan etika berpengaruh signifikan terhadap perilaku tidak etis akuntan.

\section{Saran}

Saran untuk penelitian selanjutnya yaitu dengan menambah sampel yang digunakan sehingga dapat menambah akurasi dalam penelitian ini. Memperluas scope penelitian seperti persepsi dari akuntan professional, auditor, pendidik, dan pemerintahan.

\section{DAFTAR PUSTAKA}

Adi, E. K, Fitriana R, \& Hasrin A. 2019. Persepsi Mahasiswa Jurusan Akuntansi Terhadap Perilaku Tidak Etis Akuntan ( Studi Kuantitatif Pada Mahasiswa Politeknik Negeri Samarinda. SEBATIK 1410-3737.

Damayanthi, P. A., \& Juliarsa, G. 2016. Pengaruh Idealisme, Relativisme, Pengetahuan, Gender Dan Umur Pada Perilaku
Tidak Etis Akuntan. E-Jurnal Akuntansi Universitas Udayana, Vol.15.1., 1-16.

Diwi, D. 2015. Pengaruh Orientasi Etis dan Gender terhadap Persepsi Mahasiswa Mengenai Perilaku Tidak Etis Akuntan (Studi Pada Mahasiswa S1 Jurusan Akuntansi Universitas Negeri Yogyakarta). Skripsi. Program Studi Akuntansi Jurusan Pendidikan Akuntansi Fakultas Ekonomi: Universitas Negeri Yogyakarta.

Indah, K. D. L, \& Wayan, I.R. 2019. Persepsi Etis Mahasiswa Akuntansi Atas Perilaku Tidak Etis Akuntan. E-Jurnal Akuntansi Universitas Udayana Vol.27.1.April (2019): 201-229

Keraf, Dr. A. Sonny. 1998. Etika Bisnis, Tuntutan dan Relevansinya. Kanisius. Yogyakarta

Kholifah, I. N. 2018. Pengaruh Idealisme, Relativisme, dan Pengetahuan Etika Terhadap Persepsi Mahasiswa Akuntansi atas Perilaku Tidak Etis Akuntan. Jurnal Kajian Ilmiah Akuntansi Fakultas Ekonomi UNTAN, Vol 7, No 2.

Mardawati, R. 2014. Pengaruh Orientasi Etis, Gender, Dan Pengetahuan Etika Terhadap Persepsi Mahasiswa Akuntansi Atas Perilaku Tidak Etis Akuntan (Studi pada Mahasiswa Akuntansi Universitas Negeri Yogyakarta). Skripsi. Fakultas Ekonomi: Universitas Negeri Yogyakarta.

Prihanto, H. 2018. Etika Bisnis \& Profesi: Sebuah Pencarian. Depok: Rajawali Pers.

Sugiyono. 2017. Metode Penelitian Bisnis Pendekatan Kuantitatif, Kualitatif, Kombinasi, dan R\&D (3 ed.). Bandung: Alfabeta.

Sumiyantini, N. K., Sinarwati, N. K., \& Atmadja, A. T. 2017. Persepsi Mahasiswa Jurusan Akuntansi Mengenai Idealisme, Relativisme Dan Tingkat Pengetahuan Pada Perilaku Tidak Etis Akuntan (Studi Mahasiswa Jurusan Akuntansi Universitas Ganesha). e-journal S1 Ak Universitas Pendidikan Ganesha, Vol. 7.

Widiyanto, M. A. 2013. Statistika Terapan Konsep \&Aplikasi SPSS/LISREL dalam Penelitian Pendidikan, Psikologi 
121 AKUNSIKA, Vol 1, No 2, Juli 2020, hal 11 - 20

\& Ilmu Sosial Lainnya. Jakarta: PT ElexMedia Komputindo.

Yudiaatmaja, F. 2013. Analisis Regresi Dengan Menggunakan Aplikasi Komputer Statistik SPSS. Jakarta: Gramedia Pustaka Utama.

Yuliani, K. S. 2019. Pengaruh Orientasi Etika, Tingkat Pengetahuan dan Gender terhadap Persepsi Mahasiswa Mengenai Perilaku Tidak Etis Akuntan. Jurnal Sains, Akuntansi dan Manajemen. Universitas Mahasaraswati Denpasar, Vol. 1, No. 1 